\title{
INVESTIGATION ON THE GLOBAL DISTRIBUTION OF INVASIVE FISH SPECIES, CONVICT CICHLID AMATITLANIA NIGROFASCIATA (PERCIFORMES, CICHLIDAE) OVER THE PAST YEARS WITH EMPHASIS ON IRANIAN INLAND WATERS
}

Ali Reza RADKHAH * and Soheil EAGDERI **

*, ** University of Tehran, Faculty of Natural Resources, Department of Fisheries, Karaj, Iran, alirezaradkhah@ut.ac.ir,soheil.eagderi@ut.ac.ir

DOI: 10.2478/trser-2020-0017

KEYWORDS: Amatitlania nigrofasciata, distribution, native species, Namak Lake.

\section{ABSTRACT}

The aim of this study was to investigate the global distribution of a non-indigenous and invasive fish species, the convict cichlid Amatitlania nigrofasciata, over time, with an emphasis on the inland waters of Iran. The results showed that the distribution range of the convict cichlid was initially based in Central America. Then, the distribution range of this species expanded to parts of North America. Finally, this fish species was introduced to other parts of the world such as Australia, Israel, Italy, Colombia, Germany, Peru, Slovakia, Japan, Indonesia, the Philippines, and Iran due to its extensive ability to spread. So far the presence of A. nigrofasciata has been reported in two domestic basins in Iran, namely Hormuz and Namak Lake. This study indicated that the distribution range of this species is not currently wide, but it is likely to expand towards the central plateau and southern parts of Iran.

RÉSUMÉ: Enquête sur la répartition mondiale des espèces de poissons envahissantes, condamner le cichlidé Amatitlania nigrofasciata (Perciformes, Cichlidae) au cours des dernières années en mettant l'accent sur les eaux intérieures iraniennes.

L'objectif de cette étude était d'étudier la répartition mondiale des espèces de poissons non indigènes et envahissantes, le cichlidé Amatitlania nigrofasciata au fil du temps en mettant l'accent sur les eaux intérieures de l'Iran. Les résultats ont montré que la répartition du cichlidé bagnard était initialement concentrée en Amérique Centrale. Ensuite, la répartition de cette espèce s'est étendue à certaines parties de l'Amérique du Nord. Enfin, cette espèce de poisson a été introduite dans d'autres parties du monde telles que l'Australie, Israël, l'Italie, la Colombie, l'Allemagne, le Pérou, la Slovaquie, le Japon, l'Indonésie, les Philippines et l'Iran en raison de sa grande capacité de propagation. Selon les résultats obtenus en Iran, la présence d' A. nigrofasciata a été signalée jusqu'à présent dans deux bassins domestiques de ce pays, dont les lacs Ormuz et Namak.

REZUMAT: Investigarea distribuției globale a speciei de pești invazivi, ciclidul Amatitlania nigrofasciata (Perciformes, Cichlidae) în ultimii ani, cu accent pe apele interioare iraniene.

Scopul acestui studiu a fost de a investiga distribuția globală în timp a speciei de pește non-nativă și invazivă, ciclidul Amatitlania nigrofasciata, cu accent pe apele interioare ale Iranului. Rezultatele au arătat că arealul de distribuție a acestui ciclid a fost iniţial concentrat în America Centrală. Apoi, arealul de distribuție a acestei specii s-a extins în diferite părți din America de Nord. În cele din urmă, această specie de pești a fost introdusă în alte părți ale lumii, cum ar fi Australia, Israel, Italia, Columbia, Germania, Peru, Slovacia, Japonia, Indonezia, Filipine și Iran, datorită capacității sale ridicate de răspândire. Potrivit constatărilor din Iran, până acum a fost raportată prezența speciei A. nigrofasciata în două bazine interioare din această țară, Hormuz și lacul Namak. 


\section{INTRODUCTION}

Cichlids are a group of fish belonging to the family Cichlidae (Order Perciformes) (Coad, 2019). According to some recent reports, more than 1,600 species of cichlids have been described so far, many of which are popular aquarium fish (*,2019).

Amatitlania (Schmitter-Soto, 2007) is a Neotropical genus belonging to the Cichlidae family that is distributed in Central America, from El Salvador and Guatemala to Panama (Froese and Pauly, 2019a). Researcher Juan Schmitter-Soto first described this genus in 2007 based on a study of the Archocentrus complex (Duffy et al., 2013). Schmitter-Soto (2007) stated that the genus Amatitlania is closely related to the genera Archocentrus (Gill, 1877) and Cryptoheros (Allgayer, 2001). According to Froese and Pauly (2019a), there are currently nine known species in the genus Amatitlania, including A. coatepeque (Schmitter-Soto, 2007), A. nanolutea (Allgayer, 1994), A. siica (Bussing, 1974), A. siquia (Schmitter-Soto, 2007), A. altoflava (Allgayer 2001), A. septemfasciata (Regan, 1908), A. myrnae (Loiselle, 1997), A. kanna (Schmitter-Soto, 2007), and $A$. nigrofasciata (Günther, 1867).

The convict cichlid (Amatitlania nigrofasciata) is one of the most important aquarium species in the ornamental fish industry. This species was first described in 1867 by Albert Günther as Heros nigrofasciatus (Radkhah and Eagderi, 2019). Subsequently, it was renamed Cichlasoma nigrofasciatum and Archocentrus nigrofasciatus, respectively (CABI, 2020). The type locality of this species was Amatitlán Lake in Guatemala (Radkhah and Eagderi, 2019). In 2007, according to some studies, the genus Archocentrus was moved to a new genus called Amatitlania (Schmitter-Soto, 2007; CABI, 2020). The convict cichlid has several synonyms, including Heros nigrofasciatus, Archocentrus nigrofasciatus, Cryptoheros nigrofasciatus, Cichlasoma nigrofasciatum, and Astronotus nigrofasciatus (NCBI 2019; Froese and Pauly, 2019b).

According to the information obtained, the broad environmental tolerance, the ability to occupy damaged habitats, opportunism, parental care, and rapid growth have all contributed to the offensive nature of the convict cichlid (A. nigrofasciata) (Radkhah and Eagderi, 2019; CABI, 2020). It should be noted that so far significant ecological effects of this species on native fish have been reported in different countries (CABI, 2020). For example, Tippie et al. (1991) stated that the presence of A. nigrofasciata reduced the populations of other fish species such as the White River springfish (Crenichthys baileyi). Contreras-MacBeath et al. (1998) also found that this fish species has negative effects on the population of Mexican fishery species, including Amphiphilophus istlanus and Ictalurus balsanus. Mendoza et al. (2015), confirmed the negative effects of the convict cichlid, stating that this species can compete with native fish due to its omnivorous diet and aggressive and territorial behaviours. These studies suggest that the introduction of the convict cichlid to new freshwater ecosystems may have significant negative ecological consequences.

Given the invasive nature of the convict cichlid (A. nigrofasciata) and its negative impact on freshwater ecosystems, this study aims to investigate the global distribution pattern of this fish species over the past years with emphasis on the Iranian inland waters.

The information presented in this study can be used by fishery managers to make management-conservation decisions and policies in the future. 


\section{MATERIAL AND METHODS}

In the present study, the occurrence data on the convict cichlid (A. nigrofasciata) were collected from Global Biodiversity Information Facility (GBIF) available at www.gbif.org.

Initially, based on the obtained data, the distribution maps of the species were prepared with the GBIF website over different time periods. Then, shortcomings of the maps were examined by reviewing the references and literature in scientific journals and search engines (Yogurtcuoglu and Freyhof, 2020).

In this study, some field investigations and evaluations carried out in the Iranian drainage basins over the past years were used to investigate the distribution range of A. nigrofasciata in this country. As shown in figure 1, Iran has 19 main drainage basins, which include Urmia Lake, the Caspian Sea, Dasht-e Kavir, Dasht-e Lut, Bedjestan, Tedzhen, Namak Lake, the Tigris, Karun, Kor River, Maharlu Lake, Kerman, Esfahan, Sistan, Mashkid, Jaz Murian, Makran, Hormuz, and the Persian Gulf.

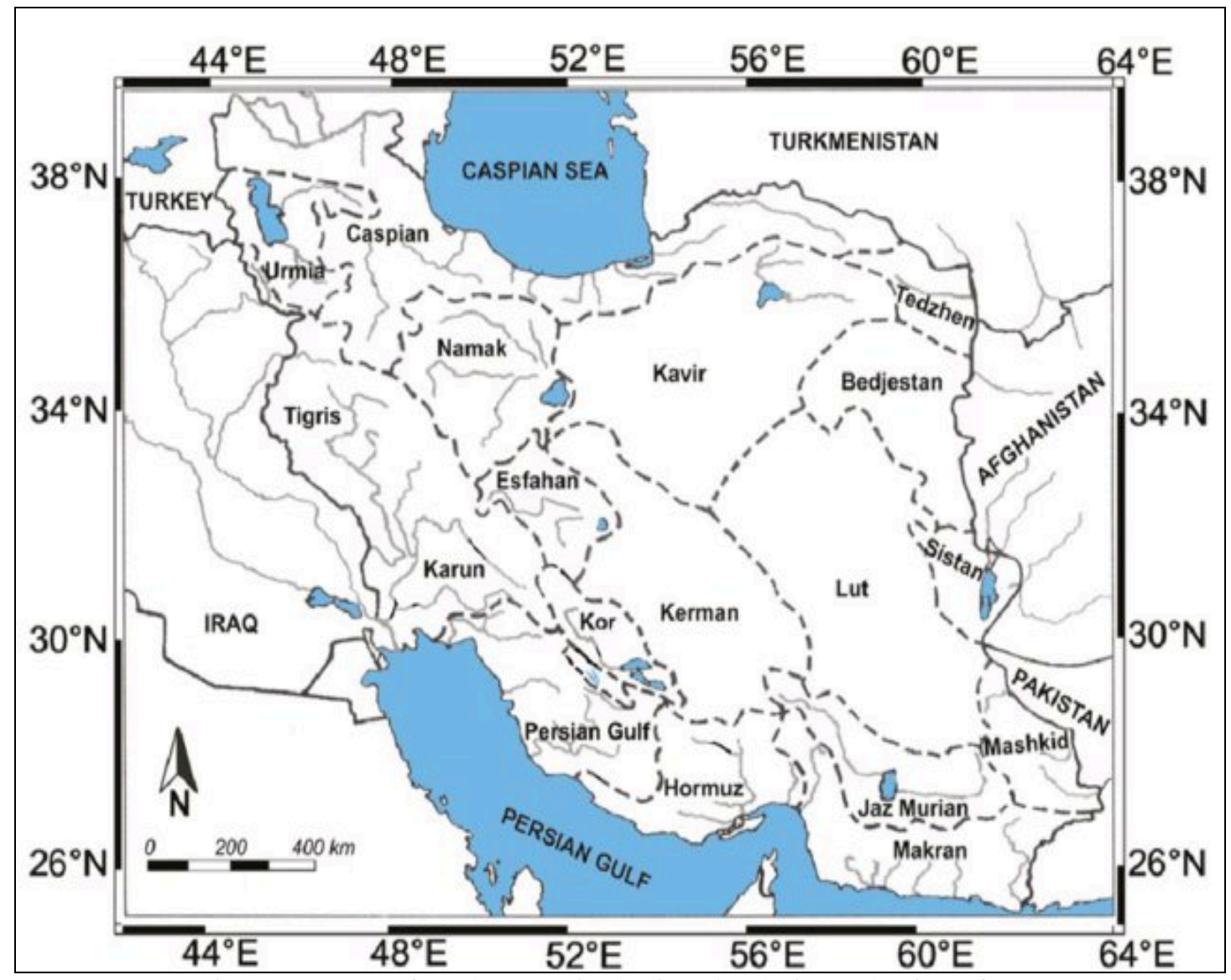

Figure 1: Map of study areas including the drainage basins of Iran

(Extracted from Teimori et al., 2016). 


\section{RESULTS}

Information on the presence of the convict cichlid in the years from 1900 to 2020 is shown in figure 2.

In addition, the global distribution maps of this fish species are presented in four time periods in figures 3-6.

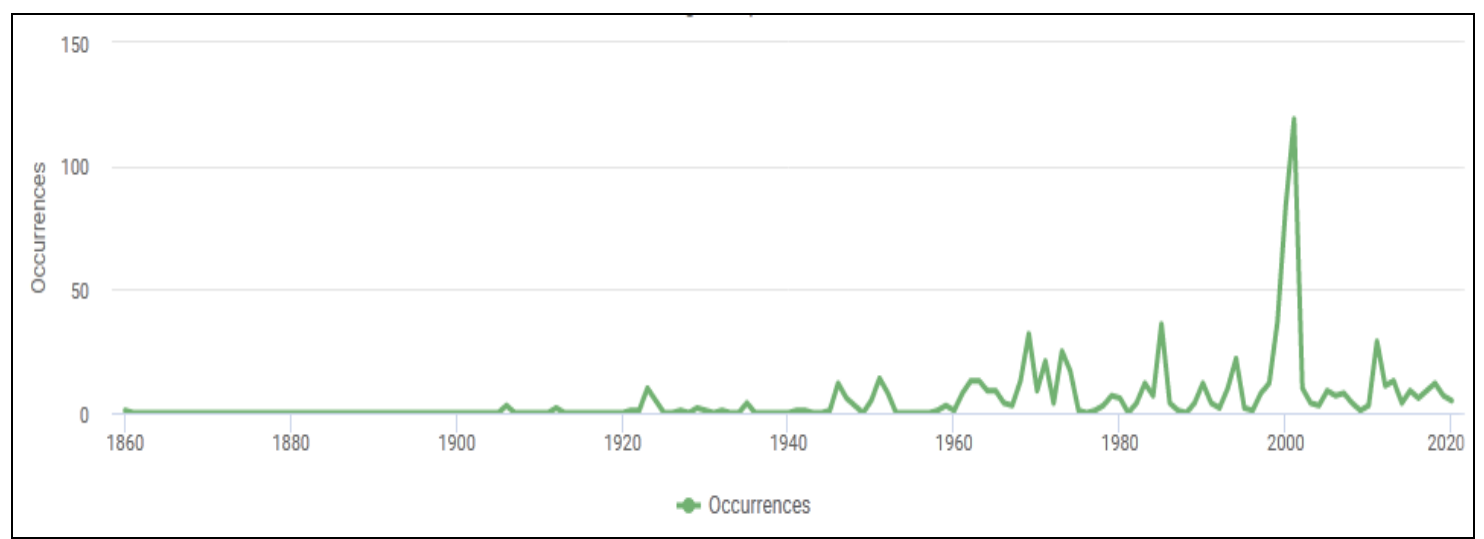

Figure 2: Information on the occurrence of $A$. nigrofasciata worldwide over time (GBIF).

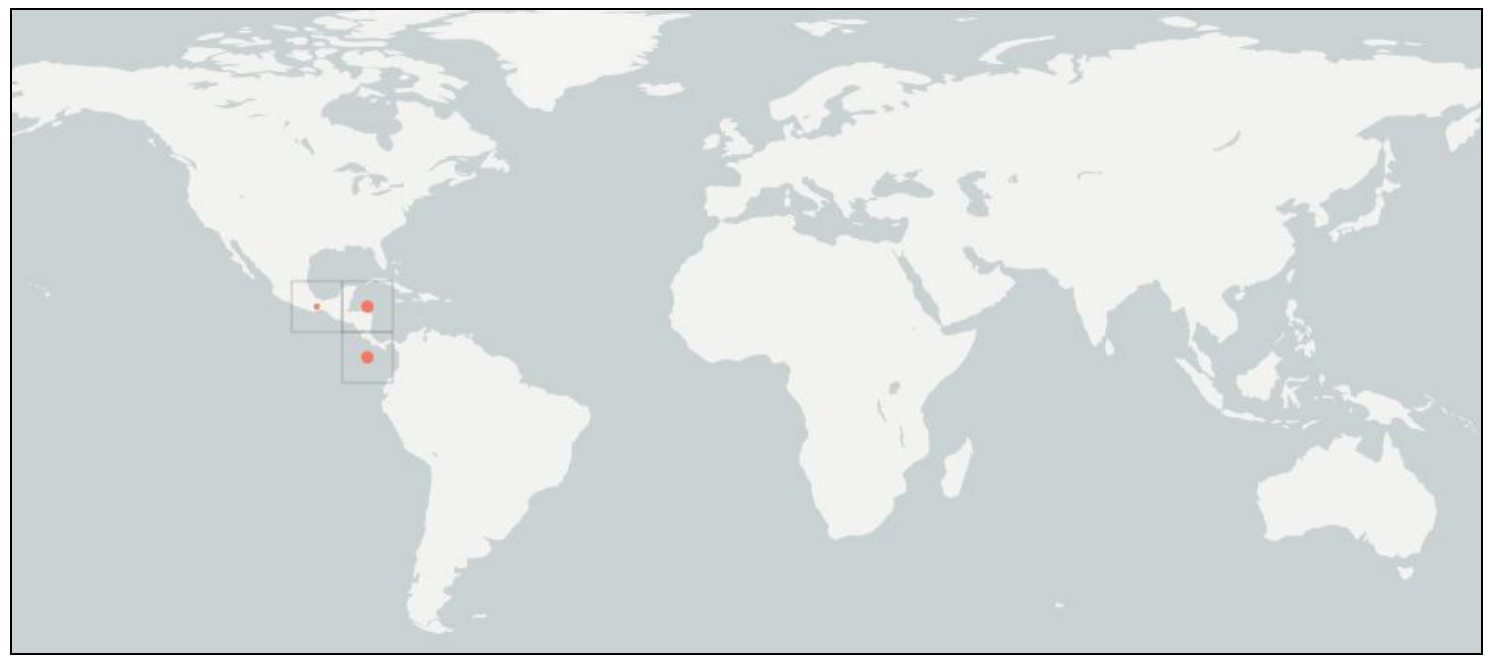

Figure 3: Global distribution of A. nigrofasciata in the years 1900-1950

(GBIF). 


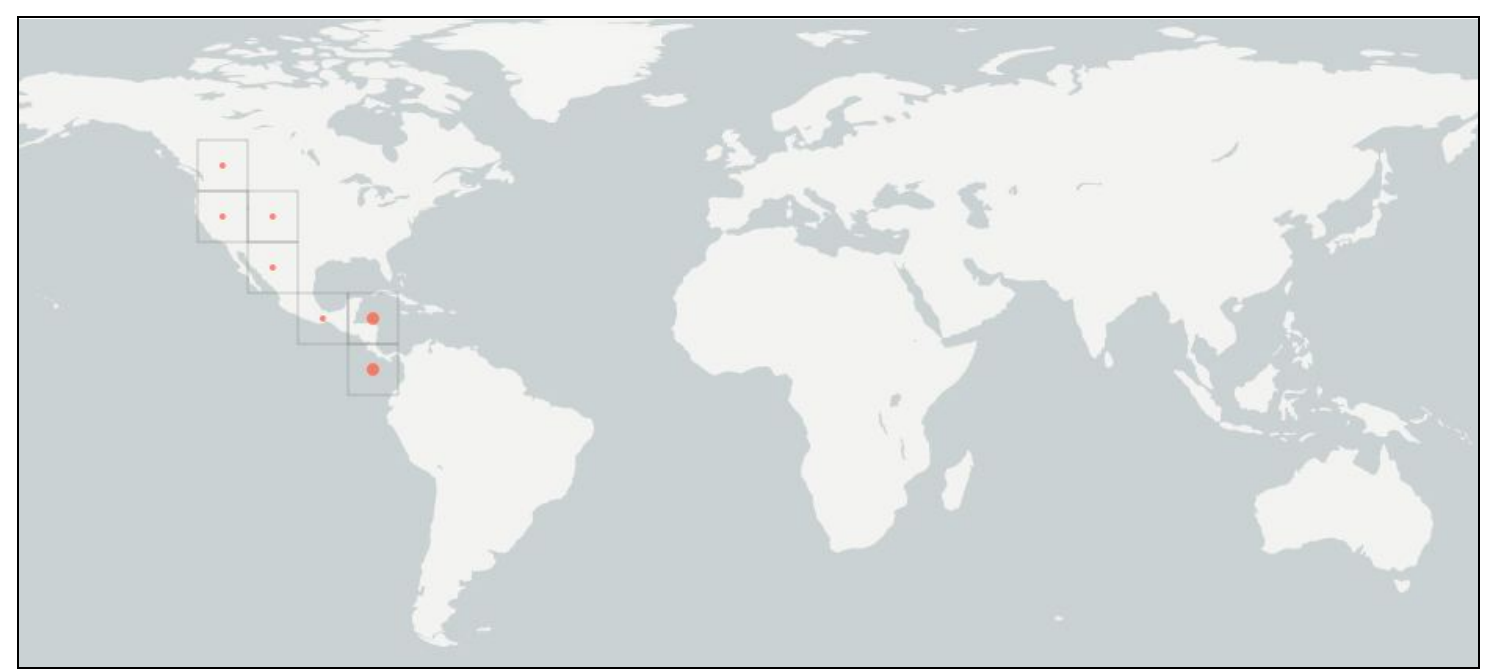

Figure 4: Global distribution map of A. nigrofasciata in the years 1950-1970 (GBIF).

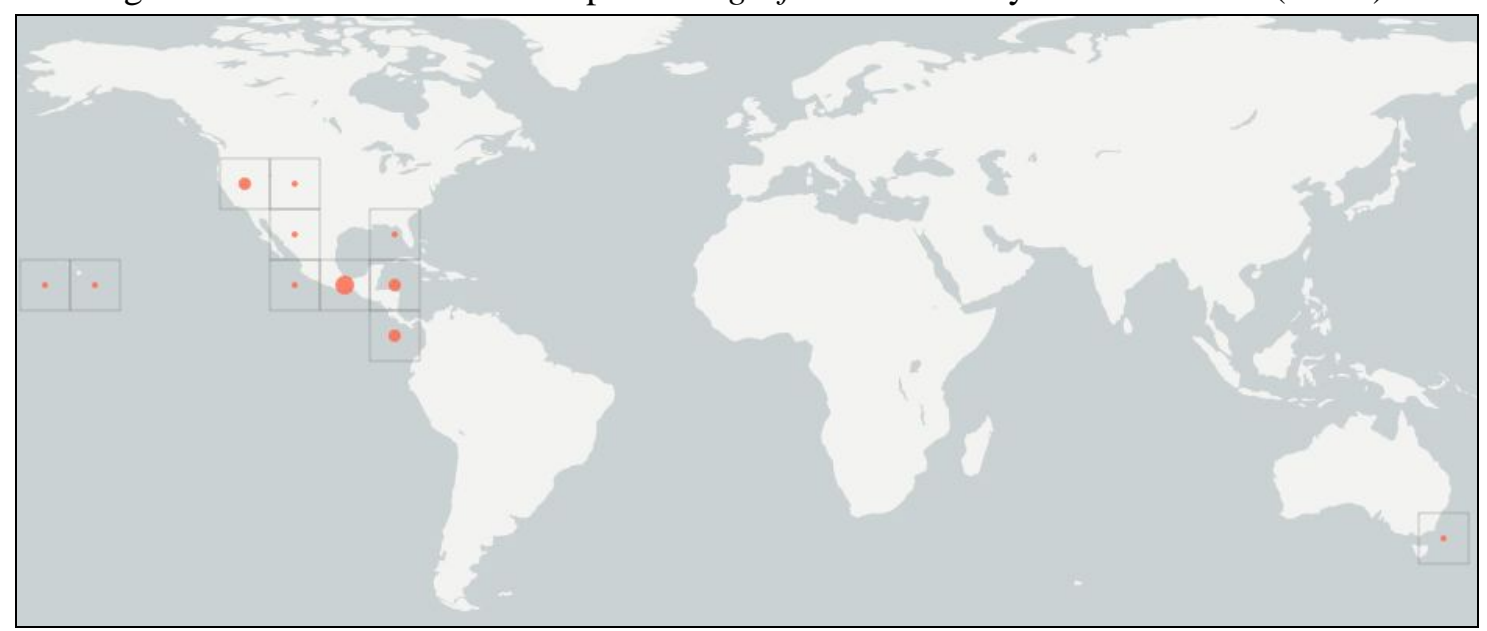

Figure 5: Global distribution map of A. nigrofasciata in the years 1970-2000 (GBIF).

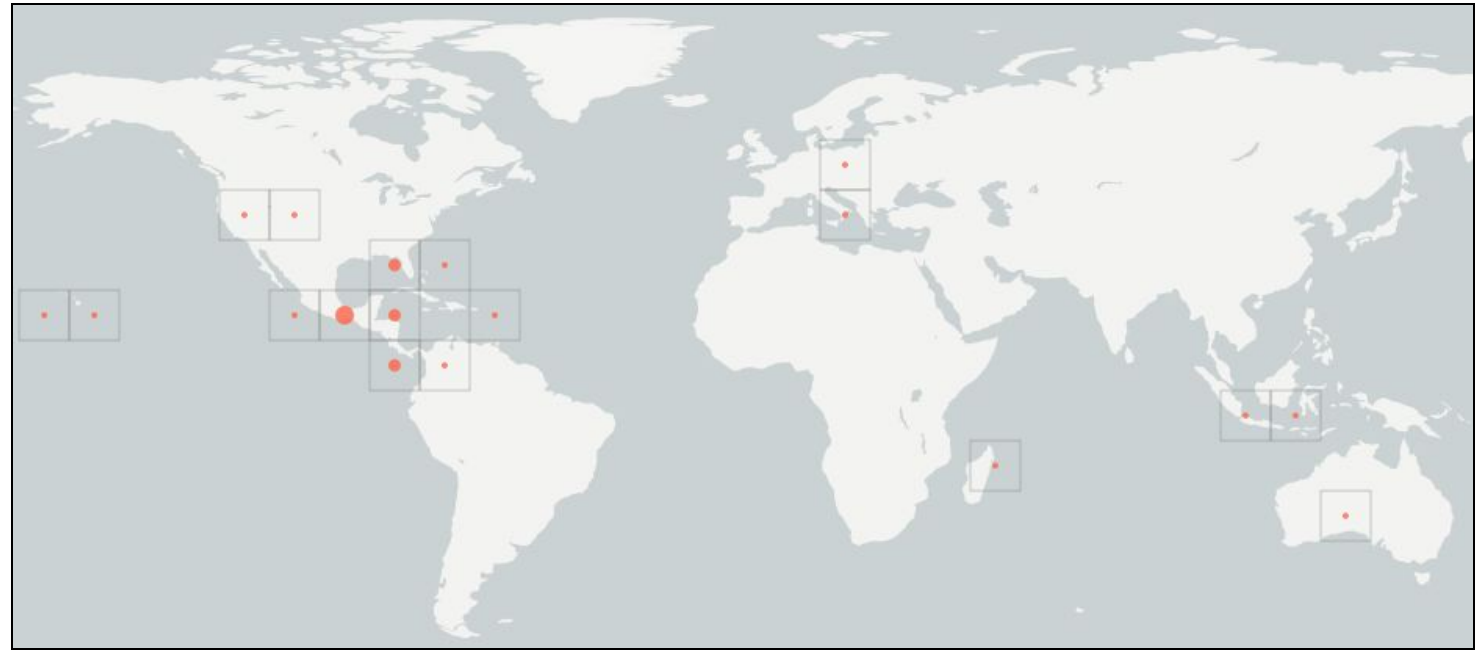

Figure 6: Global distribution map of A. nigrofasciata in the years 2000-2020 (GBIF). 
Regarding the distribution of the convict cichlid (A. nigrofasciata) in Iran, a review of the scientific sources showed that two reports on the presence of this species have been prepared so far for the inland waters of Iran. The first report was presented by Esmaeili et al. (2013), the second by Mousavi-Sabet and Eagderi (2016) (Figs. 7-8).
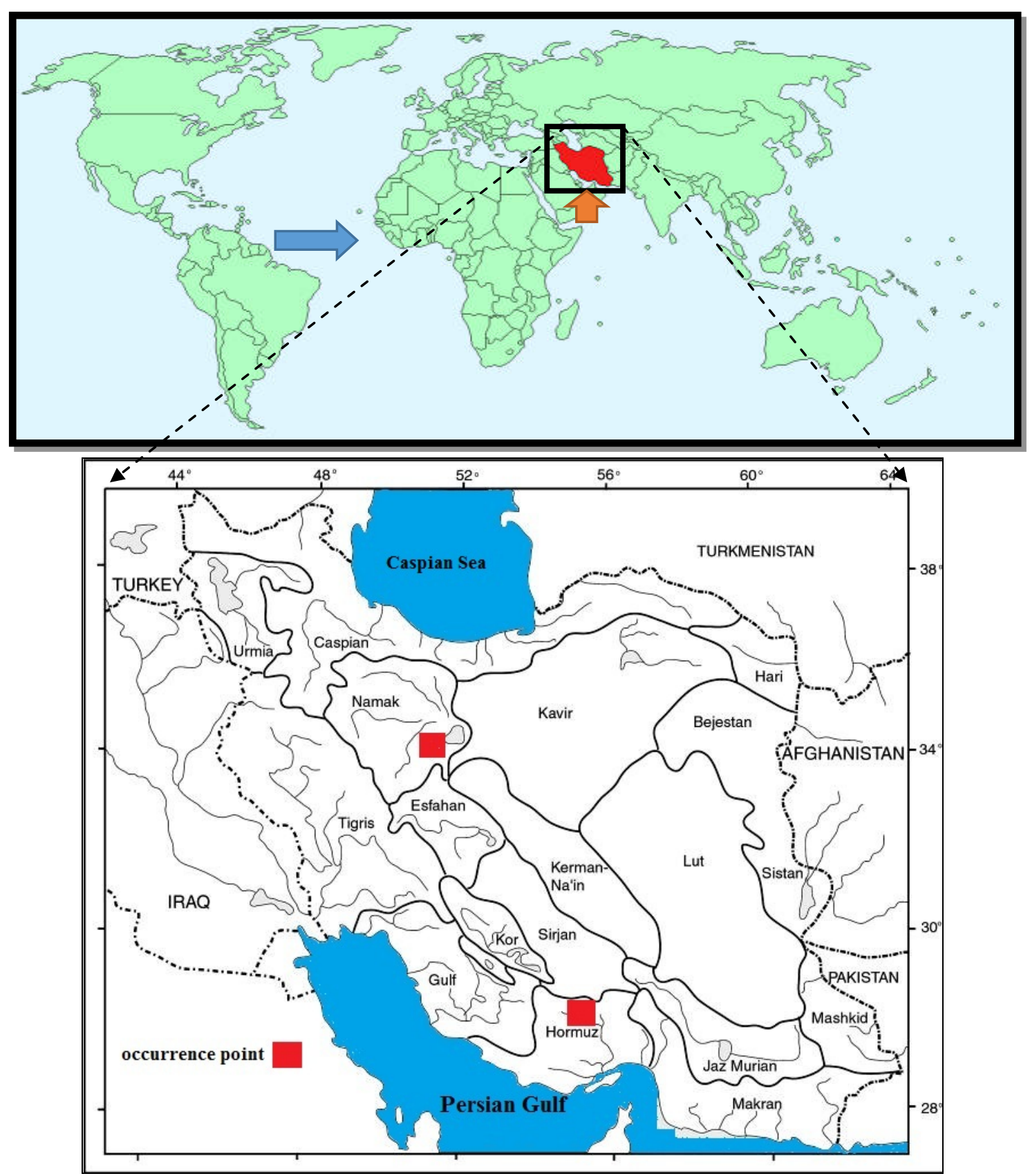

Figures 7-8: Introduction of the convict cichlid from the Neotropical region

(Central and South America) to other countries such as Iran;

The geographic distribution map of the convict cichlid in the Iranian inland basins (Map source: Coad, 2019). 
The convict cichlid (A. nigrofasciata), as one of the popular aquarium species in the ornamental fish industry (Lukas et al., 2017), has been imported into Iran from the Neotropical region (Esmaeili et al., 2017). According to recent reports, the occurrence of this species has been recorded in two domestic basins of Iran. A. nigrofasciata was first reported by Esmaeili et al. (2013) from the Kol River, the Hormuz Basin (Fig. 9a). Subsequently, its occurrence in the Namak Lake basin (Sulaymaniyah Spring) was recorded by Mousavi-Sabet and Eagderi (2016) (Fig. 9b). Those researchers stated that the convict cichlid may have been introduced into the internal ecosystems of Iran by local people as an ornamental fish species. In explaining this, they acknowledge that since the Kashn City (located in Isfahan Province) is the largest centre of ornamental fish production in Iran, it is likely that this species has been transferred from ornamental fish breeding and rearing centres of Kashan to the Sulaymaniyah Spring. The examination of the distribution map of this species in the inland waters of Iran shows that, although the occurrence of this species has been recorded in only two localities in Iran so far, it can still spread widely if urgent management decisions are not taken

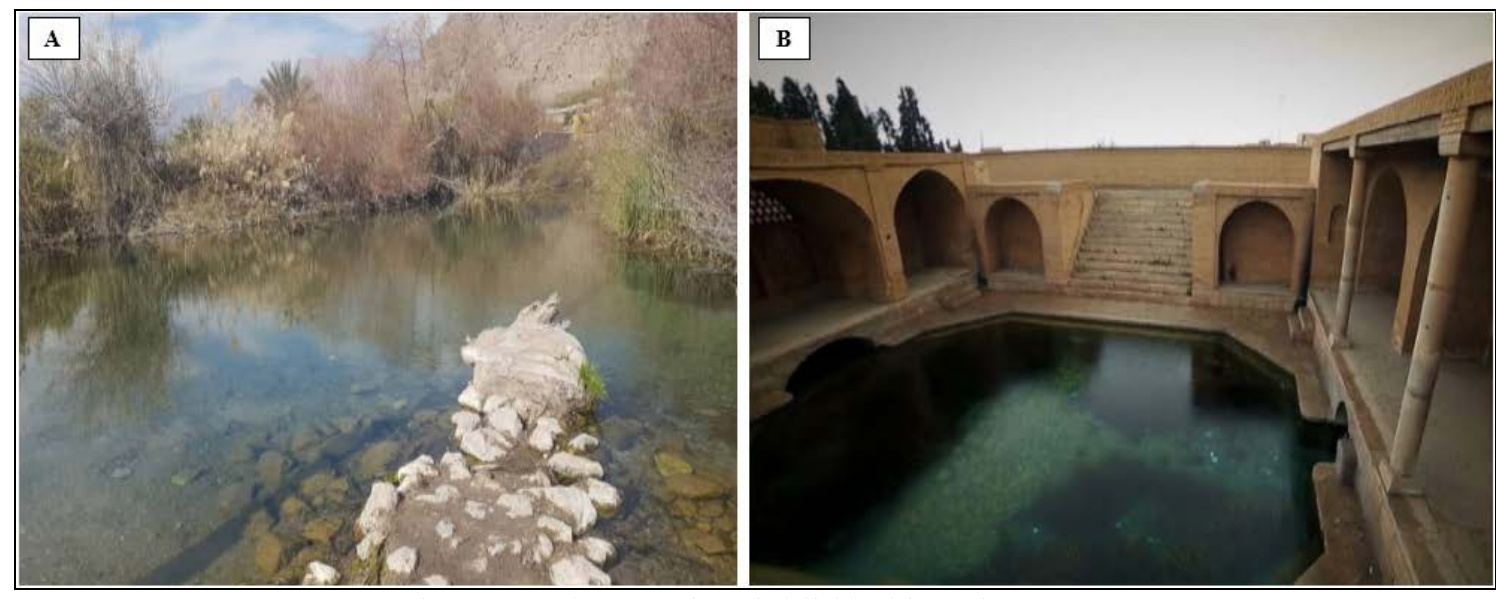

Figure 9: The convict cichlid habitats in Iran.

(A) Golabi spring (Hormuz Basin), (B) Sulaymaniyah Spring (Namak Lake basin).

(http://amernews.ir and https://www.nabro.ir).

The examination of the presence of the convict cichlid (A. nigrofasciata) over the past years showed that the highest number of reports on this species is observed in 2000 (Fig. 2). However, it should be noted that fewer reports in other years does not indicate a lower presence of the species.

The results of the distribution maps showed that from the 1900s to the 1950s, the distribution range of $A$. nigrofasciata was restricted to Central America. This result has been confirmed by Ishikawa and Tachihara (2010) and Zworykin (2011). They stated that the convict cichlid (A. nigrofasciata) is distributed in the rivers of Central America, from Guatemala to North Panama.

From the 1950s to the 1970s, the presence of A. nigrofasciata was recorded in significant parts of the Americas, such that USGS (2019) and CABI (2020) recently reported that this species has been recorded in a large number of United States of America states, including Florida, Texas, Arizona, Idaho, California, Alabama, Wyoming, Louisiana, Nevada, and Hawaii, as well as Puerto Rico. 
The examination of the global distribution of the convict cichlid (A. nigrofasciata) from the 1970s to the 2020s showed that this species had a wide potential to be introduced to different parts of the world. Evidence of this potential spread is the introduction from Central America to all continents except Antarctica, during this period.

It should be noted that some of the information about the presence of A. nigrofasciata has not been registered on the GBIF website. Therefore, the shortcomings of this data were compensated by reviewing the previous sources. One of the available references that can be used to cover this shortage is CABI that has provided new reports on the distribution of the convict cichlid. CABI (2020) stated that in addition to the presence of the convict cichlid in the mentioned countries (Fig. 6), this species has been introduced to many other countries, such as Israel, Colombia, Germany, Peru, Slovakia, the Philippines, and Iran (Fig. 10).

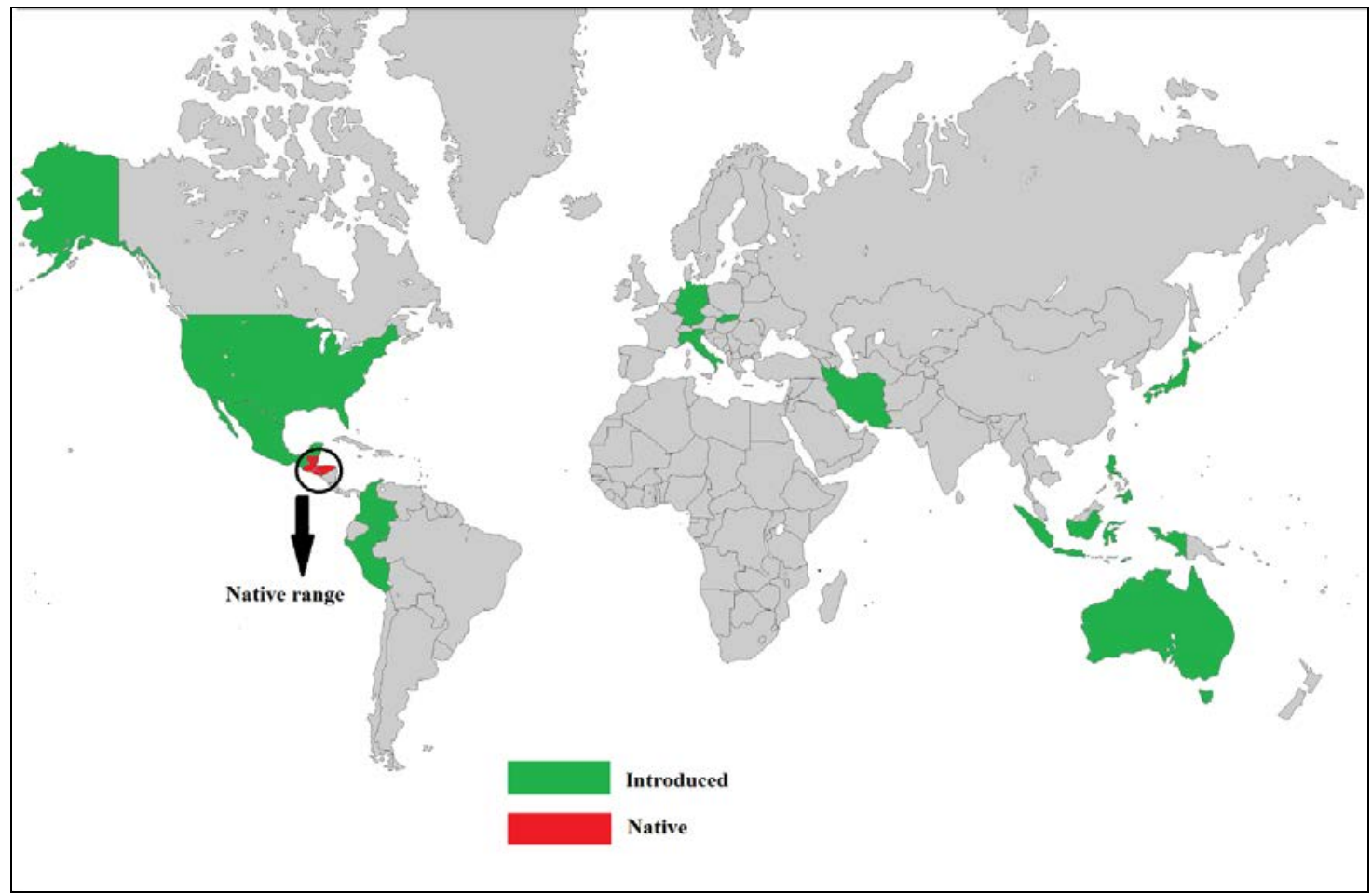

Figure 10: Global distribution map of the convict cichlid (A. nigrofasciata) based on CABI (2020).

\section{Ecological impact}

Examination of experiences and studies in different countries may be very helpful in better understanding the ecological threats posed by the convict cichlid in water bodies. In recent years, several studies in the United States of America have documented the ecological impact of this species on other fish populations. According to Deacon et al. (1964), the occurrence of the convict cichlid has reduced the population of the native Rhinichthys osculus in Lake Mead, Nevada. In addition, this species has been identified as a serious threat to populations of Crenichthys baileyi and other native fish in the White River in Nevada (USGS, 2019). According to other reports, this species has also reduced the growth of native fish in the Hiko springs of Nevada (USGS, 2019; Radkhah and Eagderi, 2019). 


\section{Possible ecological impact in the inland waters of Iran}

In a study reporting the occurrence of the convict cichlid in the Sulaymaniyah Spring, Mousavi-Sabet and Eagderi (2016) stated that this species may have negative effects on native fish as Capoeta aculeata through competition, habitat changes and introduction of parasites and diseases. Esmaeili et al. (2013) also reported on the occurrence of other species from the Golabi Spring, including Garra persica, Paraschistura sargadensis, Capoeta saadii, Carrasius auratus, Cyprinion microphthalmus, Gambusia holbrooki, and Carasobarbus luteus. All of these species are native to the Golabi Spring except G. holbrooki and C. auratus. This result indicates that a significant number of species native to this spring may be affected by a non-native species such as the convict cichlid (Radkhah and Eagderi, 2019). Esmaeili et al. (2013) acknowledged that although the distribution of the convict cichlid is very limited in the Golabi Spring, it is still likely to succeed. In fact, this spring is distinct from the other water bodies and aquatic species such as the convict cichlid cannot be transferred to other parts without human intervention. Therefore, careful monitoring and control of these areas could prove useful in maintaining population structure and biodiversity in other different ecosystems.

\section{Probability of expansion of distribution range in Iran}

Temperature is one of the most important parameters in fish distribution. According to Froese and Pauly (2019b), A. nigrofasciata lives in the temperature range of $20^{\circ} \mathrm{C}-$ $36^{\circ} \mathrm{C}$, which is related to the tropical zone. However, it is also likely for this fish to be distributed in the subtropical climate due to its high adaptability to new environmental conditions.

Given that Iran has different climates, it is possible that the distribution range of A. nigrofasciata extends into the Central Plateau and southern parts of this country (Fig. 11). Since the increase in air temperature affects the water temperature, this phenomenon can alter the habitat conditions for the successful presence of $A$. nigrofasciata. In fact, this condition can be very important for the adaptation of the species to the environmental conditions and its reproductive success in the future.

It should be noted that although the convict cichlid (A. nigrofasciata) is likely to be distributed in the Central Plateau and southern parts, the possibility of its presence in other parts of the country is not excluded. Studies have shown that this fish species has been recorded in many areas of the world that differ greatly in their environmental conditions (Radkhah et al., 2018, 2019a, b, 2020). The examination of some previous references indicates that many species of Neotropical origin have been introduced to other countries so far. According to the reports, certain species such as Poecilia reticulata and $P$. latipinna have been introduced from these areas into the Iranian inland waters (Radkhah et al., 2018, 2019a). The uncontrolled widespread dispersal of these fish over time has led to their recognition as dominant species in many freshwater systems (Radkhah and Eagderi, 2019b). Our studies show that, despite the widespread distribution of other invasive fish species in Iran, A. nigrofasciata has not yet been able to greatly expand its distribution range in the country. However, it is necessary to take some required measures to control and prevent the ecological threats posed by this fish species in Iran (Radkhah and Eagderi, 2019b). 


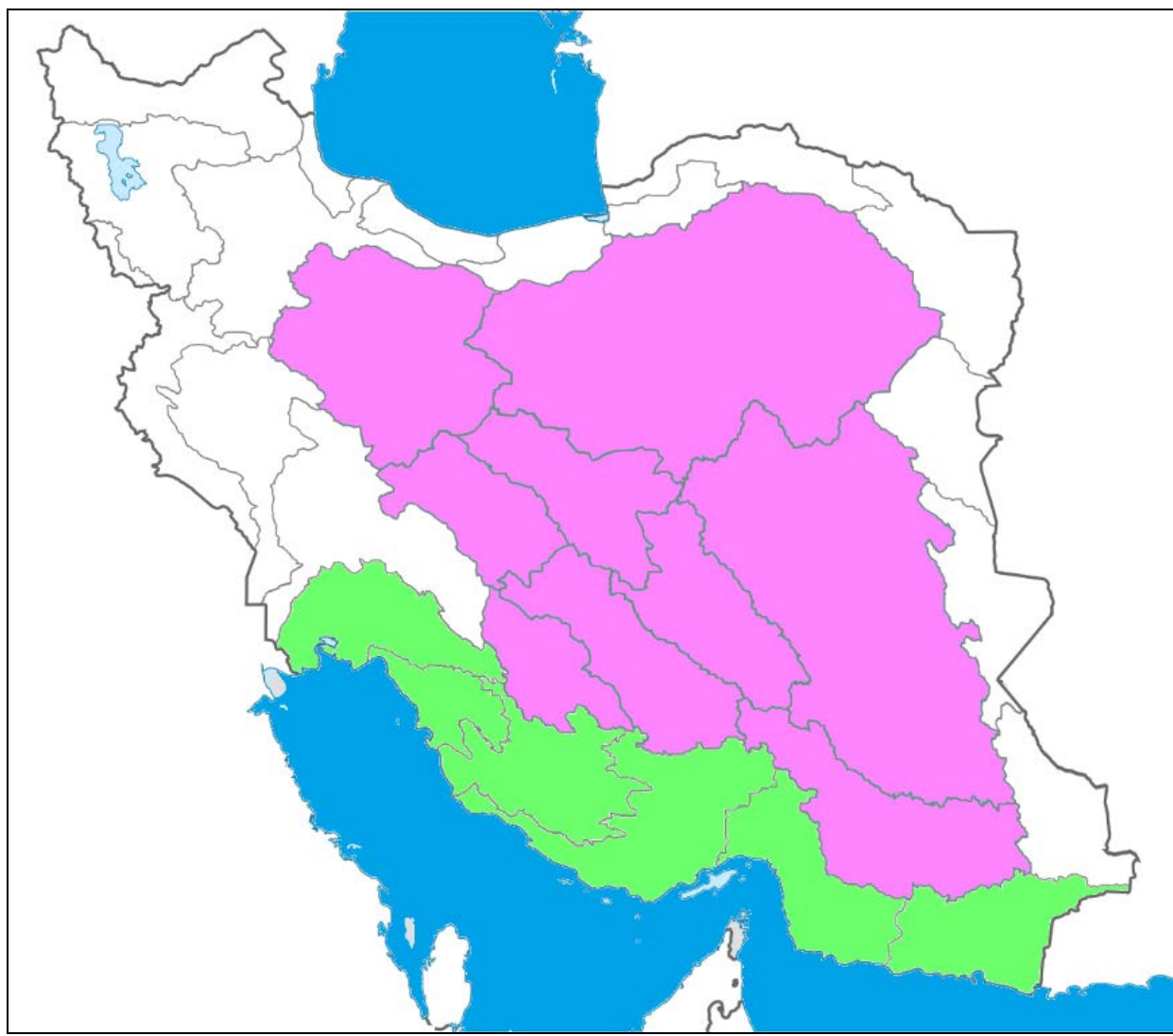

Figure 11: Expected areas for distribution of the convict cichlid (A. nigrofasciata) in fresh waters of Iran; pink and green colors show the Central Plateau and southern parts of Iran.

\section{CONCLUSIONS AND FUTURE PERSPECTIVES}

The present study indicated that the distribution area of the convict cichlid (A. nigrofasciata) was originally restricted to Central America. Subsequently, the area extended to North America and covered significant parts of the Americas. The widespread distribution of $A$. nigrofasciata continued until the presence of this species was recorded in various countries, including Australia, Israel, Italy, Colombia, Germany, Peru, Slovakia, Japan, Indonesia, the Philippines and Iran. The results of our study, which focused on the distribution of $A$. nigrofasciata in the Iranian inland waters, showed that this species has been reported in two domestic basins, including Hormuz and Namak Lake.

This study showed that the convict cichlid, due to its specific biological characteristics such as tolerance to a wide range of environmental conditions, opportunism, aggression, ability to capture disturbed habitats, and rapid growth, is capable of posing ecological threats to aquatic ecosystems. Ichthyologists have reported that the negative effects of non-indigenous species such as the convict cichlid are more likely to take a heavy toll on the native fish in the area. This species may have negative impact on the native fish populations of the country such as fish species belonging to the genus Capoeta. Hence, due to the negative impact of the introduced non-native and invasive species into native ecosystems, it is necessary to take appropriate control measures to prevent further spread. This study recommends that the national and international environmental and fishery organizations should engage broadly and sustainably to achieve this important goal. 


\section{ACKNOWLEDGEMENTS}

The authors would like to acknowledge the University of Tehran, Faculty of Natural Resources, for their support and contribution to this study.

\section{REFERENCES}

1. CABI, 2020 - Centre for Agriculture and Bioscience International, https://www.cabi.org/isc/datasheet/112202, accessed 2 May 2019.

2. Coad B. W., 2019 - Freshwater fishes of Iran, www.briancoad.com.

3. Contreras-MacBeath T., Mojica H. M. and Wilson R. C., 1998 - Negative impact on the aquatic ecosystems of the state of Morelos, Mexico, from introduced aquarium and other commercial fish, Aquarium Sciences and Conservation, 2, 2, 67-78.

4. Deacon J. E., Hubbs C. and Zahuranec B. J., 1964 - Some effects of introduced fishes on the native fish fauna of southern Nevada, Copeia, 384-388.

5. Duffy R., Snow M. and Bird C., 2013 - The convict cichlid Amatitlania nigrofasciata (Cichlidae): first record of this non-native species in Western Australian water bodies, Records of the Western Australian Museum, 28, 7-12.

6. Esmaeili H. R., Gholamifard A., Sayyadzadeh G., Parsi B., Mirghiasi S. and Ghasemian S., 2013 - New record of the convict cichlid, Amatitlania nigrofasciata (Günther, 1867), from the Middle East (Actinopterygii: Cichlidae), Aqua, International Journal of Ichthyology, 19, 4, 225-229.

7. Esmaeili H. R., Masoudi M., Chermahini M. A., Esmaeili A. H., Zarei D. and Ebrahimi M., 2017 - Invasion of the Neotropical and Nearctic fishes to Iran, FishTaxa, 2, 3, 126-133.

8. Froese R. and Pauly D. (eds), 2019a - Species of Amatitlania in FishBase, http://www.fishbase.org, accessed 30 July 2019.

9. Froese R. and Pauly D. (eds), 2019b - Amatitlania nigrofasciata (Günther, 1867), in World Register of Marine Species, http://www.marinespecies.org, accessed 10 October 2019.

10. Ishikawa T. and Tachihara K., 2010 - Life history of the nonnative convict cichlid Amatitilania nirgofasciata in the Haebaru Reservoir on Okinawa-Jima Island, Japan, Environmental biology of Fishes, 88, 283-292, doi: 10.1007/s10641-010-9641-x.

11. Lukas J. A. Y., Jourdan J., Kalinkat G., Emde S., Wilhelm Miesen F., Jüngling H., Cocchiararo B. and Bierbach D., 2017 - On the occurrence of three non-native cichlid species including the first record of a feral population of Pelmatolapia (Tilapia) mariae (Boulenger, 1899) in Europe, Royal Society Open Science, 4, 6, 170160, doi: 10.1098/rsos.170160.

12. Mendoza R., Luna S. and Aguilera C., 2015 - Risk assessment of the ornamental fish trade in Mexico: analysis of freshwater species and effectiveness of the FISK (Fish Invasiveness Screening Kit), Biological Invasions, 17, 12, 3491-3502.

13. Mousavi-Sabet H. and Eagderi S., 2016 - First record of the convict cichlid, Amatitlania nigrofasciata (Günther, 1867) (Teleostei: Cichlidae) from the Namak Lake basin, Iran, Iranian Journal of Ichthyology, 3, 1, 25-30.

14. NCBI, 2019 - National Center for Biotechnology Information, Taxonomy browser (Amatitlania nigrofasciata); https://www.ncbi.nlm.nih.gov/Taxonomy/Browser/wwwtax. cgi?id= 74111 .

15. Radkhah A. R., Eagderi S., Poorbagher H. and Hosseini S. V., 2018 - An overview of the distribution of topmouth gudgeon (Pseudorasbora parva) in inland waters of Iran and its ecological effects, in Protection of Iranian Endemic Freshwater Fishes Conference, Fisheries Department, University of Tehran, and Iranian Society of Ichthyology, Karaj, 226-236. (in Persian)

16. Radkhah A. R. and Eagderi S., 2019a - Study on the biological characteristics and ecological challenges of convict cichlid (Amatitlania nigrofasciata Günther, 1867) in inland waters of Iran, Journal of Aquaculture Exploitation and Breeding, 9, 1, 69-80. (in Persian) 
17. Radkhah A. R., Eagderi S. and Poorbagher H., 2019b - Book Review: Fish species diversity of Fars, by Esmaeili H. R. and Teimori A., 2016, 288, Fars Environment Department, ISBN: 978600-04-5600-9, Iranian Journal of Ichthyology, 6, 2, 92-97.

18. Radkhah A. R., Eagderi S. and Sadeghinejad Masouleh E., 2020 - Investigation of antimicrobial properties of silver nanoparticles (AgNPS) to control diseases and health management in aquaculture system, Journal of Ornamental Aquatics, 7, 1, 7-15. (in Persian)

19. Teimori A., Mostafavi H. and Esmaeili H. R., 2016 - An update note on diversity and conservation of the endemic fishes in Iranian inland waters, Turkish Journal of Zoology, 40, 87102, doi: 10.3906/zoo-1407-2.

20. Zworykin D. D., 2011 - Effect of predator presence on parental behavior of convict cichlid Amatitlania nigrofasciata (Perciformes, Cichlidae), Journal of Ichthyology, 51, 116-121, doi: 10.1134/S0032945210061062.

21. *, 2019 - Encyclopaedia Britannica, https://www.britannica.com/animal. 